\title{
Bird Fauna Diversity and Habitat Evolution in Jijioara River Valley (Romania)
}

\author{
Carmen GACHE*
}

\author{
“Al. I. Cuza” University, 11A Carol I Blvd., 700505 Iași, Romania \\ "corresponding author, e-mail: cgache@uaic.ro
}

Received: January 19, 2015; Accepted: February 22, 2016; Available online: April 21, 2016; Printed: April 25, 2016

\begin{abstract}
We present our five years fieldworks' results on the birds' diversity and seasonal presence, including breeding birds' populations on the Jijioara River valley that represent part of ROSPA0042 Ponds of Jijia and Miletin rivers. We recorded 129 bird species, including some rare breeding species in Romania like Platalea leucorodia, Recurvirostra avosetta, Himantopus himantopus, including two globally threatened species Aythya nyroca and Crex crex, all of them being recorded with small number of breeding pairs in the area. During the passage, hundreds of individuals of waterfowls present and waders are present on the suitable feeding areas. In the western part of the site, we found a very high level of habitats' degradation, while the birds' diversity and effectives were presenting a constant negative trend during our study period.
\end{abstract}

Key words: Jijioara River, habitats, birds, trends.

\section{INTRODUCTION}

The Jijioara River (Gârla Morii) is one tributary river of Jijia River, the most important hydrologic basin in the Romanian Prut River basin. The Jijioara River has a length about $34 \mathrm{~km}$ and a catchment area about $237 \mathrm{~km}^{2}$. The mostly length of this river's valley was transformed into a chain of ponds (Focuri - Gropnița - Forăști Mălăești - Movileni) and one reservoir (Bulbucani Lake), with a total surface about 230 hectares (ha). The ponds have elongated form and surfaces about $35-50$ ha, the smallest being the pond Focuri ( $24 \mathrm{ha}$ ), while the reservoir Bulbucani is about $92 \mathrm{ha}$, representing a source of water for the downstream fisheries (Forăști and Movileni). The valley becomes a large swamp near Larga Jijia village, to the confluence area with Jijia River.

The climate is temperate-continental, but during the last years the summers became very hot and dry.

In the investigated area there is a mosaic of habitats: waters, some large and compact reed beds (on the tail of Bulbucani Lake and Focuri pond), swamps and floodplain meadows (the largest one in the western part of the valley, near Coarnele Caprei village, two in the north-western and western sides of Bulbucani Lake and that formed around the confluence mouth area), dry meadows, arable lands, shrubs and bushes areas, some small clusters of trees.

The access is possible only by car, following the county road Iași-Movileni - Focuri - Coarnele Caprei. It is an old and very difficult road, especially during rainfalls and in winter. The distance from Iaşi city is about $28 \mathrm{~km}$, if we visit the ponds of Jijioara River starting from south-eastern part, from the confluence mouth (Larga Jijia village) to the north-western side (Coarnele Caprei village). 
The whole valley is part of the Nature 2000 site ROSPA0042 Ponds of Jijia and Miletin Rivers, representing the western limit of this site situated around the confluence of Jijioara and Miletin Rivers with Jijia River (Papp \& Fântână, 2008, H.G. no. 1284/2007) but there is only one specific reference to the bird fauna of Jijioara valley (Müller et al., 2005). In this preliminary study report, the authors present this valley like an important feeding site for the breeding birds from Jijia ponds, but also, like a very important stop-over area during the birds' migration periods. In the reed beds from Bulbucani Lake and Focuri pond, they identified some breeding bird species that appears in the Annex 1 of Birds' Directive (Nycticorax nycticorax, Ciconia ciconia and Circus aeruginosus, like certainly breeding species, while Platalea leucorodia and Recurvirostra avosetta are presented like probably breeding species), other threes species from this annex being mentioned as non-breeding bird species in this area - Aythya nyroca, Egretta garzetta and Tringa glareola.

\section{MATERIAL AND METHODS}

We began our fieldwork in 2007, but regularly twice per month visits were done just beginning with May 2009 and the field ornithological investigations are ongoing. Visiting transect followed the county road Iași-Movileni-Focuri-Coarnele Caprei and had covered the whole perimeters of the ponds with some fixed points for birds' observation and counting in the areas with large clusters of aquatic birds and waders: Movileni (Fig. 1, A, B, C), Mălăești (Fig. 1, D, E), Forăști (Fig. 1, F), Gropnița (Fig. 1, G, H, I) and Focuri - Coarnele Caprei (Fig. 1, L, M, N), including the reservoir Bulbucani (Fig. 1, J, K).

During our monitoring activities, we followed the diversity and effectives of birds, the qualitative and quantitative seasonal and yearly dynamic in order to assess the population trend, with a special attention for the breeding bird species.

Within the whole study period, we observed the anthropogenic influences on the birds' diversity and populations, but also the habitats' evolution in the severe climate's change recorded during the last years in this area.

\section{RESULTS AND DISCUSSIONS}

We recorded 129 bird species (table 1), representing $60.66 \%$ from the whole birds list of the ROSPA0042 Ponds of Jijia and Miletin rivers, but some of them were recorded just once or twice during our study period - Tadorna tadorna (one pair, Movileni/C, 27 $7^{\text {th }}$ April 2012, respectively, two pairs, Bulbucani/K, $15^{\text {th }}$ November 2012), Aythya marila (one pair, Gropnita/I, 17 ${ }^{\text {th }}$ October 2011, respectively, 6 males and 2 females, Gropnița/H, $5^{\text {th }}$ October 2014), Bucephala clangula (2 pairs, Forăști /F, $15^{\text {th }}$ March 2010), Aquila heliaca (one adult, Movileni/C, $5^{\text {th }}$ April 2015), Phalaropus lobatus ( 2 individuals in wintering plumage, Focuri - Coarnele Caprei/M, $27^{\text {th }}$ August 2011), Xenus cinereus (one adult, Gropnița/H, $22^{\text {nd }}$ August 2012) and Larus minutus (4 individuals, Mălăești/D, 24 ${ }^{\text {th }}$ September 2010, respectively, 12 individuals, Focuri/N, $27^{\text {th }}$ August 2011).

The greatest bird diversity and effectives appear during the migration period, especially in autumn - for the waders, the first migratory flocks arrive in late July in this area, using the surfaces with shallow waters from the northern limit of Gropnitia pond, respectively, the tail of Focuri pond like feeding territories. The last migratory flocks, representing waterfowls, were recorded in the late November, every year. During the passage, hundreds of individuals of waterfowls and waders are present on 


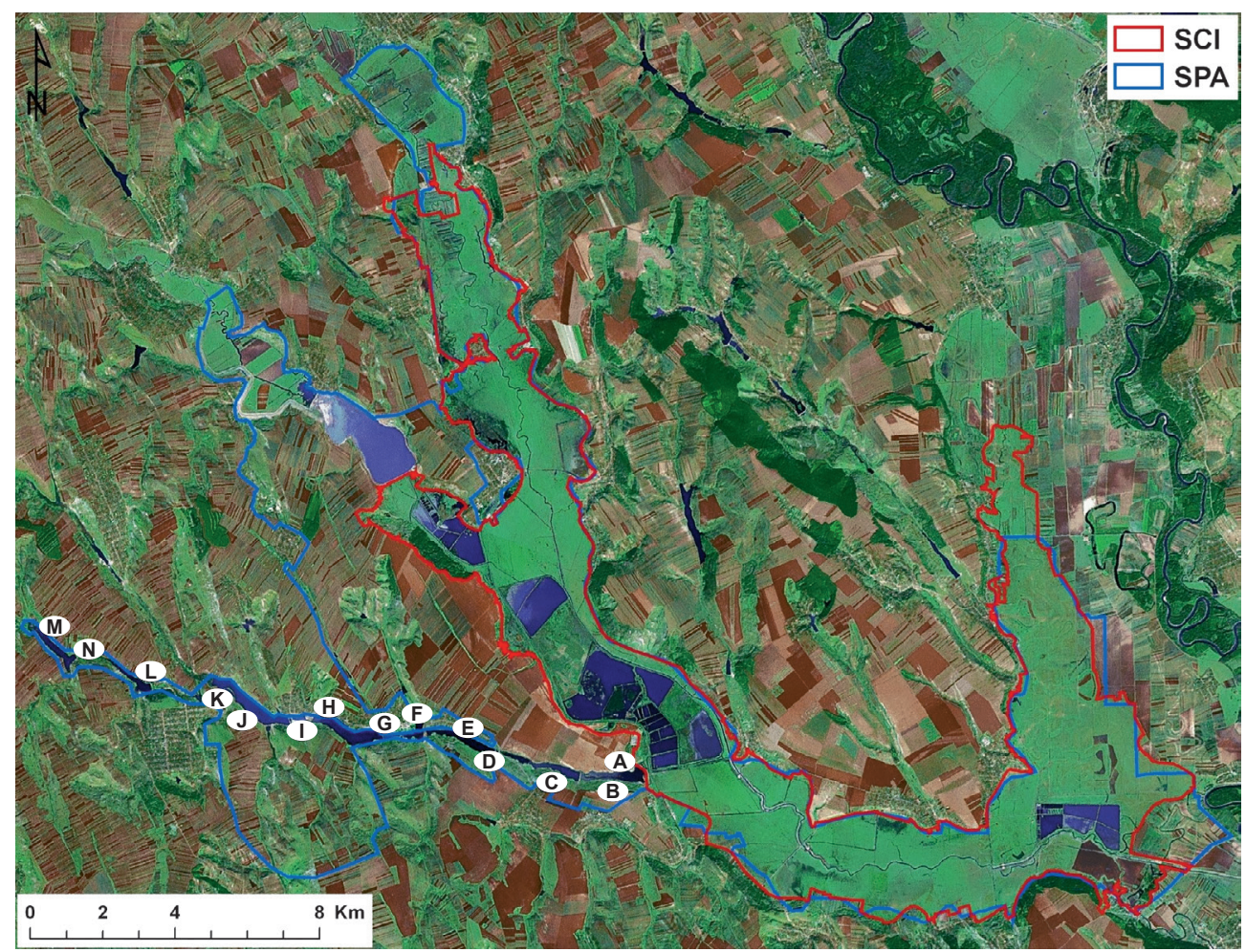

Fig. 1 - The observation stations on the Jijioara River valley (adapted from ANPM, 2007)

the suitable feeding areas, confirming the importance of this valley for the migration flyways related to the Prut River basin in the north-eastern Romania. We recorded daily counted effectives about 4000 - 6000 of ducks and gulls, respectively, $900-1750$ individuals of waders just in late September and the first half of October, when the managers of the fisheries' empty the ponds in order to facilitate the fishing activities, enlarging the suitable feeding areas.

Regarding the fish-eating birds, in the migration time, the cormorants (there we met only one species - Phalacrocorax carbo) appear in groups about 200 - 320 individuals, while the gulls and terns are breeding with very small effectives, presenting an obviously decline and are using the area like stop-over point, especially during the autumn migration.

Usually, the waters of ponds and Bulbucani reservoir are completely frozen in December or not later than the first decade of January. For this reason, the diversity and the population effectives of birds present the smallest values along wintering time.

The list of breeding birds in the investigated area brings together 81 species (63.28\% from the recorded bird fauna on the valley of Jijioara River), but all of them present small or very small effectives in the area due the small surfaces covered with suitable habitats, but also due the anthropogenic pressure. First of all, Jijioara valley crosses through the villages (three territorial administrative units: Movileni, Gropnița and Focuri), so, nor only the houses and the cultivated gardens extend to the edge of the ponds, but the domestic waterfowls (geese and ducks) are present 
The bird fauna recorded on the Jijioara River valley $(2009$ - 2014)

\begin{tabular}{|c|c|c|c|c|c|c|c|}
\hline No. & Species' name & $\begin{array}{c}\text { Breeding } \\
\text { (pairs) }\end{array}$ & $\begin{array}{c}\text { Migration } \\
\text { (individuals) }\end{array}$ & $\begin{array}{c}\text { Wintering } \\
\text { (individuals) }\end{array}$ & Trends & $\begin{array}{c}\text { Birds' } \\
\text { Directive }\end{array}$ & $\begin{array}{l}\text { Romanian } \\
\text { Red Book }\end{array}$ \\
\hline 1 & Perdix perdix & $5-10$ & $24-32$ & $12-24$ & 0 & - & - \\
\hline 2 & Coturnix coturnix & $5-8$ & $12-18$ & - & 0 & - & - \\
\hline 3 & Phasianus colchicus & $3-5$ & $?$ & $8-12$ & 0 & - & - \\
\hline 4 & Cygnus olor & $1-2$ & $8-22$ & $2-10$ & - & - & - \\
\hline 5 & Anser anser & - & $48-720$ & $120-480$ & 0 & - & - \\
\hline 6 & Anser albifrons & - & $32-910$ & $130-610$ & 0 & - & - \\
\hline 7 & Anas platyrhynchos & $4-12$ & $150-940$ & $128-232$ & 0 & - & - \\
\hline 8 & Anas strepera & $1-3$ & $18-152$ & - & - & - & - \\
\hline 9 & Anas acuta & - & $2-6$ & - & - & - & - \\
\hline 10 & Anas penelope & - & $64-262$ & $18-32$ & + & - & - \\
\hline 11 & Anas crecca & - & $52-340$ & $64-110$ & 0 & - & - \\
\hline 12 & Anas querquedula & $4-8$ & $32-122$ & - & - & - & - \\
\hline 13 & Anas clypeata & - & $4-27$ & $12-20$ & - & - & - \\
\hline 14 & Tadorna tadorna & - & $2-4$ & - & - & - & $\mathrm{V}$ \\
\hline 15 & Aythya fuligula & - & $32-56$ & $8-14$ & 0 & - & - \\
\hline 16 & Aythya marila & - & $2-8$ & - & $?$ & - & - \\
\hline 17 & Aythya ferina & $3-6$ & $34-270$ & $18-32$ & 0 & - & - \\
\hline 18 & Aythya nyroca & $1-4$ & $24-42$ & - & - & A1 & $\mathrm{V}$ \\
\hline 19 & Bucephala clangula & - & $2-12$ & - & $?$ & - & $\mathrm{V}$ \\
\hline 20 & Phalacrocorax carbo & - & $13-320$ & $2-5$ & 0 & - & - \\
\hline 21 & Ixobrychus minutus & $2-7$ & $5-7$ & - & - & - & - \\
\hline 22 & Ardeola ralloides & $3-6$ & $2-10$ & - & - & A1 & $\mathrm{T}$ \\
\hline 23 & Nycticorax nycticorax & $1-2$ & $4-21$ & - & - & A1 & $\mathrm{V}$ \\
\hline 24 & Egretta garzetta & $5-8$ & $8-43$ & - & 0 & A1 & $\mathrm{T}$ \\
\hline 25 & Ardea alba & $2-3$ & $6-36$ & $1-3$ & 0 & A1 & $\mathrm{T}$ \\
\hline 26 & Ardea cinerea & $2-5$ & $12-27$ & $2-5$ & 0 & - & - \\
\hline 27 & Ardea purpurea & $1-2$ & $2-8$ & - & - & A1 & $\mathrm{T}$ \\
\hline 28 & Platalea leucorodia & $2-5$ & $11-18$ & - & - & A1 & $\mathrm{T}$ \\
\hline 29 & Ciconia ciconia & $2-4$ & $32-112$ & - & - & A1 & $\mathrm{V}$ \\
\hline 30 & Aquila heliaca & - & $0-1$ & - & $?$ & A1 & En \\
\hline 31 & Buteo buteo & - & $2-7$ & $3-6$ & 0 & - & - \\
\hline 32 & Buteo lagopus & - & $1-3$ & $2-5$ & 0 & - & - \\
\hline 33 & Pernis apivorus & - & $2-6$ & - & 0 & $\mathrm{~A} 1$ & $\mathrm{~V}$ \\
\hline 34 & Accipiter gentilis & $1-3$ & $1-5$ & $2-4$ & 0 & - & - \\
\hline 35 & Accipiter nisus & - & $1-2$ & - & 0 & - & - \\
\hline 36 & Circus aeruginosus & $2-4$ & $4-12$ & - & + & A1 & - \\
\hline 37 & Falco columbarius & - & $1-3$ & $1-2$ & 0 & A1 & - \\
\hline 38 & Falco subbuteo & $2-3$ & $3-6$ & - & 0 & - & - \\
\hline 39 & Falco tinnunculus & $1-6$ & $5-8$ & - & + & - & - \\
\hline 40 & Crex crex & $2-5$ & $?$ & - & - & $\mathrm{A} 1$ & $\mathrm{~V}$ \\
\hline 41 & Porzana parva & $1-2$ & $?$ & - & - & $\mathrm{A} 1$ & - \\
\hline 42 & Gallinula chloropus & $4-7$ & $18-20$ & - & 0 & - & - \\
\hline
\end{tabular}

Legend: Trends (-/negative; +/positive; 0/constant; ?/insufficient data); Birds' Directive (A1 - bird species included in Annex 1 that need special conservation measures); Romanian Red Book (En - endangered species; $\mathrm{T}$ - threatened species; $\mathrm{V}$ - vulnerable species). 
Table 1 (continued)

\begin{tabular}{|c|c|c|c|c|c|c|c|}
\hline No. & Species' name & $\begin{array}{c}\text { Breeding } \\
\text { (pairs) }\end{array}$ & $\begin{array}{c}\begin{array}{c}\text { Migration } \\
\text { (individuals) }\end{array} \\
\end{array}$ & $\begin{array}{c}\text { Wintering } \\
\text { (individuals) }\end{array}$ & Trends & $\begin{array}{c}\text { Birds' } \\
\text { Directive }\end{array}$ & $\begin{array}{l}\text { Romanian } \\
\text { Red Book }\end{array}$ \\
\hline 43 & Fulica atra & $12-23$ & $24-76$ & - & 0 & - & - \\
\hline 44 & Gallinago gallinago & - & $8-18$ & - & - & - & - \\
\hline 45 & Lymnocryptes minimus & - & $4-20$ & - & - & - & - \\
\hline 46 & Calidris alba & - & $10-42$ & - & - & - & - \\
\hline 47 & Calidris alpina & - & $15-82$ & - & - & - & - \\
\hline 48 & Calidris ferruginea & - & $18-32$ & - & - & - & - \\
\hline 49 & Calidris temminckii & - & $2-8$ & - & - & - & - \\
\hline 50 & Limicola falcinellus & - & $4-22$ & - & - & - & - \\
\hline 51 & Numenius arquata & - & $12-72$ & - & - & - & - \\
\hline 52 & Limosa limosa & - & $28-232$ & - & 0 & - & - \\
\hline 53 & Actitis hypoleucos & - & $2-16$ & - & - & - & - \\
\hline 54 & Tring a glareola & - & $12-126$ & - & - & A1 & - \\
\hline 55 & Tringa ochropus & - & $6-36$ & - & 0 & - & - \\
\hline 56 & Tringa nebularia & - & $6-38$ & - & 0 & - & - \\
\hline 57 & Tringa stagnatilis & - & $8-152$ & - & 0 & - & - \\
\hline 58 & Xenus cinereus & - & $0-1$ & - & $?$ & $\mathrm{~A} 1$ & - \\
\hline 59 & Tringa totanus & - & $22-680$ & - & + & - & - \\
\hline 60 & Tringa erythropus & - & $132-420$ & - & + & - & - \\
\hline 61 & Philomachus pugnax & - & $103-286$ & - & + & A1 & - \\
\hline 62 & Phalaropus lobatus & - & $0-2$ & - & $?$ & $\mathrm{~A} 1$ & - \\
\hline 63 & Recurvirostra avosetta & $1-5$ & $5-24$ & - & - & $\mathrm{A} 1$ & $\mathrm{~V}$ \\
\hline 64 & Himantopus himantopus & $1-2$ & $2-8$ & - & - & A1 & $\mathrm{T}$ \\
\hline 65 & Charadrius dubius & $1-3$ & $6-14$ & - & - & - & - \\
\hline 66 & Vanellus vanellus & $8-21$ & $120-390$ & - & - & - & - \\
\hline 67 & Larus cachinnans & - & $46-2400$ & $12-130$ & 0 & - & - \\
\hline 68 & Larus michahellis & - & $18-32$ & - & 0 & - & - \\
\hline 69 & Larus minutus & - & $4-12$ & - & $?$ & A1 & - \\
\hline 70 & Croicocephalus ridibundus & - & $128-670$ & $24-125$ & 0 & - & - \\
\hline 71 & Sterna hirundo & $1-7$ & $23-93$ & - & - & A1 & - \\
\hline 72 & Chlidonias hybridus & $2-7$ & $12-50$ & - & - & $\mathrm{A} 1$ & - \\
\hline 73 & Podiceps cristatus & $2-5$ & $6-17$ & - & 0 & - & - \\
\hline 74 & Podiceps grisegena & - & $2-5$ & - & - & - & - \\
\hline 75 & Tachybaptus ruficollis & $1-3$ & $4-12$ & - & - & - & - \\
\hline 76 & Columba palumbus & $1-3$ & $6-24$ & - & + & - & - \\
\hline 77 & Streptopelia decaocto & $20-32$ & $?$ & $88-124$ & + & - & - \\
\hline 78 & Cuculus canorus & $12-21$ & $?$ & - & 0 & - & - \\
\hline 79 & Athene noctua & $2-3$ & $?$ & $2-4$ & 0 & - & - \\
\hline 80 & Coracias garrulus & 2 & $1-2$ & - & 0 & $\mathrm{~A} 1$ & - \\
\hline 81 & Merops apiaster & $7-10$ & $12-26$ & - & 0 & - & - \\
\hline 82 & Upupa epops & $1-2$ & $4-7$ & - & 0 & - & $\mathrm{V}$ \\
\hline 83 & Dendrocopos syriacus & $8-18$ & $?$ & $8-14$ & 0 & $\mathrm{~A} 1$ & - \\
\hline 84 & Oriolus oriolus & $13-22$ & $?$ & - & 0 & - & - \\
\hline 85 & Lanius collurio & $3-5$ & $6-13$ & - & 0 & A1 & - \\
\hline
\end{tabular}

Legend: Trends (-/negative; +/positive; 0/constant; ?/insufficient data); Birds' Directive (A1 - bird species included in Annex 1 that need special conservation measures); Romanian Red Book (En - endangered species; $T$ - threatened species; $V$-vulnerable species). 
Table 1 (continued)

\begin{tabular}{|c|c|c|c|c|c|c|c|}
\hline No. & Species' name & $\begin{array}{c}\text { Breeding } \\
\text { (pairs) }\end{array}$ & $\begin{array}{c}\text { Migration } \\
\text { (individuals) }\end{array}$ & $\begin{array}{c}\text { Wintering } \\
\text { (individuals) }\end{array}$ & Trends & $\begin{array}{c}\text { Birds' } \\
\text { Directive }\end{array}$ & $\begin{array}{l}\text { Romanian } \\
\text { Red Book }\end{array}$ \\
\hline 86 & Lanius minor & $2-4$ & $4-10$ & - & 0 & A1 & - \\
\hline 87 & Lanius excubitor & - & $4-8$ & $3-5$ & 0 & - & - \\
\hline 88 & Pica pica & $6-13$ & $8-22$ & 17 & 0 & - & - \\
\hline 89 & Corvus monedula & $10-14$ & $12-70$ & $42-50$ & - & - & - \\
\hline 90 & Corvus frugilegus & $12-22$ & $92-260$ & $120-178$ & 0 & - & - \\
\hline 91 & Corvus cornix & $4-6$ & $12-42$ & $8-28$ & 0 & - & - \\
\hline 92 & Corvus corax & - & $1-5$ & $2-4$ & + & - & $\mathrm{T}$ \\
\hline 93 & Alauda arvensis & $22-34$ & $?$ & - & 0 & - & - \\
\hline 94 & Galerida cristata & $12-16$ & $?$ & $84-128$ & 0 & - & - \\
\hline 95 & Hirundo rustica & $72-120$ & $220-410$ & - & 0 & - & - \\
\hline 96 & Delichon urbica & $48-74$ & $110-182$ & - & 0 & - & - \\
\hline 97 & Riparia riparia & $142-218$ & $114-320$ & - & + & - & - \\
\hline 98 & Acrocephalus arundinaceus & $28-60$ & $?$ & - & - & - & - \\
\hline 99 & Acrocephalus scirpaceus & $20-40$ & $?$ & - & - & - & - \\
\hline 100 & Acrocephalus schoenobaenus & $12-21$ & $?$ & - & - & - & - \\
\hline 101 & Locustella luscinioides & $3-6$ & $?$ & - & - & - & - \\
\hline 102 & Sylvia communis & $2-4$ & $5-8$ & - & 0 & - & - \\
\hline 103 & Panurus biarmicus & $12-20$ & $18-52$ & - & - & - & - \\
\hline 104 & Oenanthe oenanthe & $4-12$ & $10-14$ & - & 0 & - & - \\
\hline 105 & Saxicola torquata & $3-7$ & $8-15$ & - & - & - & - \\
\hline 106 & Saxicola rubetra & $5-8$ & $12-16$ & - & 0 & - & - \\
\hline 107 & Phoenicurus phoenicurus & $2-4$ & $4-10$ & - & - & - & - \\
\hline 108 & Phoenicurus ochruros & $7-10$ & $3-10$ & - & + & - & - \\
\hline 109 & Turdus merula & $8-12$ & $34-42$ & $18-32$ & 0 & - & - \\
\hline 110 & Turdus philomelos & $2-4$ & $56-82$ & - & + & - & - \\
\hline 111 & Turdus pilaris & - & $18-320$ & $62-260$ & + & - & - \\
\hline 112 & Turdus viscivorus & - & $120-410$ & - & - & - & - \\
\hline 113 & Sturnus vulgaris & $45-62$ & $830-3400$ & $12-42$ & + & - & - \\
\hline 114 & Troglodytes troglodytes & - & $?$ & $3-8$ & $?$ & - & - \\
\hline 115 & Parus major & $14-22$ & $22-32$ & $24-43$ & 0 & - & - \\
\hline 116 & Cyanistes coeruleus & $3-7$ & $8-12$ & $4-12$ & - & - & - \\
\hline 117 & Passer domesticus & $130-180$ & $242-540$ & $178-320$ & 0 & - & - \\
\hline 118 & Passer montanus & $32-38$ & $42-56$ & $52-64$ & - & - & - \\
\hline 119 & Motacilla alba & $6-8$ & $14-32$ & - & - & - & - \\
\hline 120 & Motacilla flava & $8-13$ & $12-26$ & - & 0 & - & - \\
\hline 121 & Anthus campestris & $12-13$ & $14-24$ & - & 0 & A1 & - \\
\hline 122 & Fringilla coelebs & $18-26$ & $26-48$ & $14-32$ & 0 & - & - \\
\hline 123 & Fringilla montifringilla & - & $42-322$ & $21-126$ & 0 & - & - \\
\hline 124 & Carduelis spinus & - & $22-34$ & $12-18$ & 0 & - & - \\
\hline 125 & Carduelis chloris & $14-21$ & $32-46$ & - & + & - & - \\
\hline 126 & Carduelis carduelis & $12-18$ & $134-230$ & $32-112$ & 0 & - & - \\
\hline 127 & Carduelis cannabina & $2-5$ & $8-20$ & - & 0 & - & - \\
\hline 128 & Miliaria calandra & $8-19$ & $14-33$ & - & 0 & - & - \\
\hline 129 & Emberiza schoeniclus & $12-23$ & $22-32$ & $18-25$ & 0 & - & - \\
\hline
\end{tabular}

Legend: Trends (-/negative; +/positive; 0/constant; ?/insufficient data); Birds' Directive (A1 - bird species included in Annex 1 that need special conservation measures); Romanian Red Book (En - endangered species; $\mathrm{T}$ - threatened species; $\mathrm{V}$ - vulnerable species). 
with effectives of hundred individuals everywhere - the exception are Movileni and Focuri Ponds, respectively, southern side of Bulbucani reservoir. In some areas, the fishermen's presence is constant (Movileni ponds) and of large herds of sheep and cattle, too (Movileni and Mălăești ponds, Bulbucani reservoir). Moreover, with just few exceptions (nine species), the breeding populations had recorded a constant negative trend (Fig. 2). If we look for the exceptions, we notice the presence of four species that are synanthropic or opportunistic species (Streptopelia decaocto, Phoenicurus ochruros, Sturnus vulgaris and Carduelis chloris), but also two raptor species. For the Marsh Harrier (Circus aeruginosus) we recorded four breeding pairs in 2012 and 2013 , three of them in the area of Focuri pond, respectively, one in the reed beds from the tail of Bulbucani reservoir, while the Common Kestrel was recorded like breeding species in 2007 with just one pair, one trio in 2009 and formed one colony of 6 pairs starting from 2013' spring in the poplars along the road near the fisheries Focuri.

The list of breeding birds includes some rare breeding species in Romania like Platalea leucorodia, Recurvirostra avosetta, Himantopus himantopus and some species with negative trend in our country like Ardeola ralloides, Anas strepera or Porzana parva, most of them being vulnerable or threatened bird species (Botnariuc \& Tatole, 2005). Between the globally threatened bird species, we mention the Ferruginous Duck (Aythya nyroca) and the Corncrake (Crex crex), both of them being vulnerable species in Romania. Looking for the species included in the Annex 1 of Birds' Directive (2009/147/EC), that need special conservation measures in order to prevent their decline and risk of extinction, we can notice the presence of 20 breeding species, most of them related to the wetland and aquatic habitats, other 7 species occurring during the migration period and one in winter.

The diversity of birds, but also, their effectives present a constant negative trend, especially, during the last about three years due the reduction of wetlands and the surface of some ponds, but also due the constant degradation of habitats in some points of investigated area. The marshes and swampy areas are near dissapeared during the last years in the area. Two decades ago, Jijioara River form a lerge swampy area at the confluence with Jijia River, covering about 2.5 hectares, but now, the most of this is grassy and reed bed surfaces. A similar evolution was recorded in the southern side from the tail of Bulbucani reservoir, while the swampy areas from the observatory point

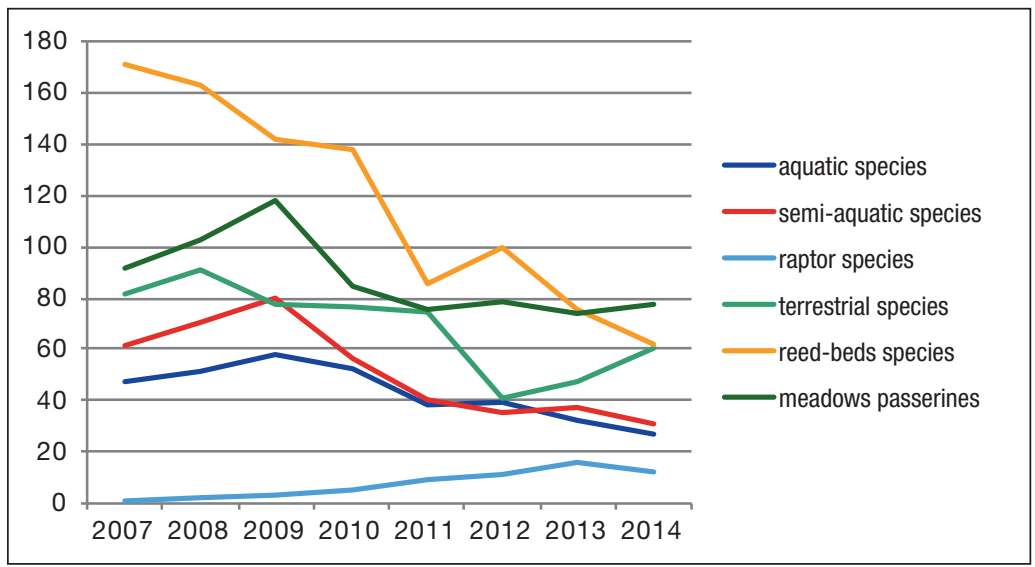

Fig. 2 - The trends of breeding bird populations on the Jijioara River valley 
J (Bulbucani reservoir), respectively, point M (Focuri - Coarnele Caprei) dissapeared completely, now appearing like grassland or invaded by reed.

This situation is the result of the erosion phenomenon and prolonged drought, but also of the mismanagement of fisheries that accelerated the clogging of some ponds, especially in the western side of the valley. For example, ten years ago, the waters were covering near the whole distance between the villages Focuri and Coarnele Caprei, about $11 \mathrm{~km}$ length while now, the surface of the pond Focuri is not larger than 24 ha. In the summer of 2011 it was thoroughly dry for some hydrotechnical improvements, but in the spring of 2014, the mostly part of this area seems to be completely abandoned and the existant fishery closed definetely. The surface of the reed bed increased in the absence of the water, but the quality of these reed beds was very low, so, currently, the aquatic and semi-aquatic birds did not use to build their nests or feed in this area. Nor the reed passerines (especially, Locustella sp. and Acrocephalus sp.) were not recorded in this perimeter, probably the absence of the water affecting the life cycle of the insects that serve as their food resources. If the degradation of the habitats continues perhaps we must think seriously to remove this perimeter from the territory of ROSPA0042 Ponds of Jijia and Miletin Rivers.

On the other hand, some of small ponds in the Forasti fishery remained without water in summers of 2011 and 2012, while the surfaces of Gropnița pond and Bulbucani reservoir were significantly reduced due the severe drought recorded in these years. As we saw during our fieldwork, the greatest threatening factor for the biodiversity in this part of Romania is the fact that numerous fisheries are going to close due a combination of elements - the economical constraints, high costs of water supply (the ponds are supplied with water by pumping), the low volumes of water due the drought and the imposition to implement a friendly-fishery management to protect the bird diversity and effectives. The disappearing of these fisheries means that the special protected areas for birds are losing their support and will disappearing, too.

One very serious problem is that the site has not a caretaker nor a management plan despite the fact that now is the sixth year of its existence and represents one of the most important wetlands in eastern Romania. The authorities decided to put together this ROSPA0042 Pond of Jijia and Miletin Rivers with the ROSCI0122 Salty meadows of Jijia and Prut River, forming a huge area about 25,000 ha, with ten territorial administrative units and eight fisheries on this territory. The Romanian Ornithological Society had done a constant monitoring of the bird fauna from the area - especially, the ponds of Jijia and Miletin Rivers - starting from 1992 and tried to become the caretaker, but abandoned this project 18 months later due the lack of financial and logistic support.

The responsibilities of the caretaker for one Nature 2000 site are huge - the minimum set of conservation measures must be ready in the first six months after taking in custody the site, while the protected area's rules, including the restrictive measures and, also, the plan of management must be elaborated and sent to the environmental authorities in one year. Till now, the central authorities seem to not understand that an appropriate plan of management can be elaborated and implemented only if these activities involve all stakeholders from the area, either economic agents, local communities, local and central authorities or specialists in the monitoring and conservation of biodiversity. 


\section{CONCLUSIONS}

Jijioara River valley represents the western part of one of the most important wetlands from the north-eastern Romania, ROSPA0042 Ponds of Jijia and Miletin Rivers.

The bird fauna's list includes 129 species, 81 being breeding species in the area. Excepting 9 species, the breeding bird species present negative trends in this territory.

We recorded 28 bird species that need special conservation measures in order to prevent their decline and risk of extinction (Birds' Directive, Annex 1) and 17 bird species included in the Romanian Red Book of Vertebrates.

In the western part of the site, we found a very high level of habitats' degradation, the birds' diversity and effectives presenting constant negative trend during our study period.

The abandonment of existing fisheries will determine losses of the support for the present protected biodiversity.

\section{REFERENCES}

BOTNARIUC, N., V. TATOLE (2005) Cartea Roşie a vertebratelor din România [Red Book of the Vertebrates from Romania], Muzeul Național de Istorie Naturală. „Grigore Antipa”, Bucharest, 260 pp. (in Romanian)

MÜLLER, J. W., C. GACHE, A. E. IGNAT (2005) Contributii la identificarea unor situri Natura 2000 în județele Moldovei, Analele Bucovinei, 12 (2): 553-565. (in Romanian)

PAPP, T., C. FÂNTÂNĂ (eds) (2008) Ariile de Importanță Avifaunistică din România [Important Birds Area in Romania], Romanian Ornithological Society \& Milvus Group's publication, Tg. Mureş, Romania, 319 pp.

*** (2007) Guvernul României: HG nr. 1284/2007 privind declararea ariilor de protecție specială avifaunistică ca parte integrantă a rețelei Natura 2000 în România. Monitorul Oficial, I, 739/31.10.2007, București (in Romanian)

*** (2009) European Union: Directive 2009/147/EC of the European Parliament and of the Council of 30 November on the conservation of wild birds 